\title{
MORPHOLOGICAL TRAITS AS TOOL TO VERIFY GENETIC VARIABILITY OF INTERSPECIFIC DRAGON FRUIT HYBRIDS ${ }^{1}$
}

\author{
ADRIANA DE CASTRO CORREIA DA SILVA ${ }^{2}$, RAFAEL ROVERI SABIÃO ${ }^{3}$, \\ FERNANDO MARCELO CHIAMOLERA ${ }^{3}$, DANIELA MOTA SEGANTINI ${ }^{4}$, \\ ANTONIO BALDO GERALDO MARTINS ${ }^{5}$
}

\begin{abstract}
With recent cultivation in Brazil, the dragon fruit still have lacks related to the selection of promising materials and there are not yet commercial varieties in the country. Therefore, manual pollination cross were held in 2010, between plants of $H$. undatus $\mathrm{x} H$. polyrhizus and H. undatus $\mathrm{x} H$. setaceus. Aiming evaluate the genetic diversity of the progenies for future use in breeding program, based on cladodes characteristics, six characters were assessed: length and diameter of stem, distance between areoles, arch height, number and size of spines/areole. From the Euclidean distance matrix analysis was constructed a dendrogram by the UPGMA method. There was great variability among hybrids, and eight of them have shown promise for use in breeding program.
\end{abstract}

Index terms: genetic relationship, multivariate analysis, Hylocereus undatus, H. polyrhizus, $H$. setaceus.

\section{CARACTERIZAÇÃO MORFOLÓGICA PARA ESTUDO DA DIVERGÊNCIA GENÉTICA DE HÍBRIDOS INTERESPECÍFICOS DE PITAYA ${ }^{1}$}

RESUMO-De cultivo recente no Brasil, a pitaya ainda carece de estudos relacionados à seleção de materiais promissores, não havendo, até o momento, nenhuma variedade comercial registrada no País. Assim, realizaram-se polinizações cruzadas entre plantas de Hylocereus undatus $\times H$. polyrhizus e H. undatus $\times H$. setaceus. Baseando-se em características do cladódio, avaliou-se a divergência genética das progênies, visando à utilização futura em programa de melhoramento genético. Foram avaliados seis caracteres: comprimento e diâmetro dos ramos, distância entre aréolas, altura das costilhas, número e tamanho dos espinhos por aréola. A análise de agrupamento pelo método UPGMA foi feita a partir da matriz de distância Euclidiana. Houve grande variabilidade entre os híbridos, e oito deles mostraram-se promissores para serem utilizados em programa de melhoramento genético.

Termos para indexação: análise multivariada, pitaya-vermelha, diversidade genética, variabilidade genética.

\footnotetext{
'(Paper 170-15). Received June 29, 2015. Accepted April 12, 2016.

${ }^{2}$ Agr. Eng., Dr., Universidade Estadual de Mato Grosso do Sul, UEMS, Unidade Universitária de Aquidauana. Rod AquidauanaPiraputanga, km 12, Aquidauana-MS, 79200-000, Brazil. E-mail: adrianacastro@uems.br;

${ }^{3}$ Agr. Eng., M. Sc., PhD students in Agronomy at Faculdade de Ciências Agrárias e Veterinárias, UNESP - Univ. Estadual Paulista, Jaboticabal Campus, Dept. of Plant Production, Jaboticabal-SP, 14884-900, Brazil. E-mail: rrsabiao@yahoo.com.br; chiamolera@ hotmail.com

${ }^{4}$ Agr. Eng., Dr., Faculdade de Ciências Agronômicas, UNESP - Univ. Estadual Paulista, Botucatu Campus , Dept. of Horticulture, 18610-307, Botucatu-SP, Brazil. E-mail: dani_segantini@hotmail.com

${ }^{5}$ Agr. Eng., Dr., Fruitculture Professor, Faculdade de Ciências Agrárias e Veterinárias, UNESP - Univ. Estadual Paulista, Campus de Jaboticabal, Dept. of Plant Production, Jaboticabal-SP, 14884-900, Brazil. E-mail: baldo@fcav.unesp.br
} 


\section{INTRODUCTION}

Cultivated in Brazil just over a decade, the pitaya still lacks in studies related to the selection of promising materials. There is, so far, no commercial variety registered in the country. The external and internal appearance of the fruits, mainly as to the coloring, is what differentiates the types of pitayas. Four species are of commercial importance in the country, Hylocereus undatus, H. polyrhizus, $H$. setaceus (Sin.: Selenicereus setaceus) and H. megalanthus (Sin.: S. megalanthus).

In most orchards, the producers themselves multiply their material by cutting, which guarantees the uniformity of the orchard and the precocity of production. Thus, the orchards show practically no variability, which is ideal for marketing purposes, but undesirable in terms of plant genetic improvement. For variability induction, seed propagation may be a resource to be exploited since the plants obtained by sexual propagation may be similar to one of the parents, to both or none of them. The obtained individuals (F1 generation) will have different characteristics, being possible, from these materials, to select those with desired characteristics. Therefore, researches aiming at the species improvement are of great value, since they can result in the selection of more vigorous and productive materials and fruits of better quality than those currently available. In the pitayas, because they have a narrow genetic base, the accomplishment of interspecific hybridizations is facilitated (TEL-ZUR et al., 2004), allowing to join, from these controlled crosses, favorable characteristics of different species, being able to obtain new varieties with specific characteristics such as fruit quality.

In order to characterize germplasm variability, the use of molecular markers such as RAPD (Random Amplified Polymorphic DNA) and ISSR (Inter Simple Sequence Repeats) have been widely used (JUNQUEIRA et al., 2010a; JUNQUEIRA et al., 2010b; TAO et al., 2014) however it is possible, through the description of morphological characteristics, to verify the variability of a set of plants. Pitaya presents great ecotypic diversity, and species can be defined according to the characteristics of cladodes, flowers and fruits (ORTIZ HERNÁNDEZ; CARRILLO SALAZAR, 2012). In some plant species, the distinction between varieties can be performed based on the morphological aspects of the plants, which allows identification when there are still no flowers and / or fruits (ANDRADE; MARTINS, 2007). So the objective of this study was to evaluate pitaya interspecific hybrids, through morphological characters related to the stem in order to separate the more dissimilar, to be used as the basis for breeding programs.

\section{MATERIAL AND METHODS}

The experiment was carried out in the Fruitculture Nursery of the Faculty of Agrarian and Veterinary Sciences of Jaboticabal (FCAV / UNESP, $21^{\circ} 14^{\prime} 33^{\prime \prime} S$ and $48^{\circ} 17^{\prime} 02^{\prime \prime} \mathrm{W}, 563 \mathrm{~m}$ altitude). The evaluated progenies were obtained from interspecific cross-pollination, carried out manually in 2010: $H$. undatus $\mathrm{x} H$. polyrhizus (L2P17); H. undatus $\mathrm{x}$ H. polyrhizus (L4P3); H. undatus х H. polyrhizus (L4P11); H. undatus x $H$. setaceus (L2P6); $H$. undatus $\times$ H. setaceus (L2P7). The denomination in brackets refers to the location of the access in the Germplasm Active Bank of the FCAV / UNESP (L: line; P: plant). The hybrids were named according to the access code of the pollen donor species, the number after the hyphen corresponding to the accession number. Altogether, 45 progenies and six parental (Table 1) were morphologically evaluated. The evaluated progenies were kept in a greenhouse, with $50 \%$ shading, cultivated in plastic pots of 11 liters, in a substrate containing soil, sand and corral manure, in a proportion of $3: 1: 1$. At the time of the evaluation they were about 3 years old and, the parents, 10 years.

The morphological characters studied were chosen based on the UPOV publication -International Union for the Protection of New Varieties of Plants (2011), with some adaptations. A total of six vegetative morphological characters related to the cladodes were recorded for each genotype, being: length and diameter of stem, distance between areoles, arch height, number and size of the spines per areole. The measurements were taken from the secondary cladodes in the median portion of the stem, taking five measurements per cladodes, in three cladodes per plant (Figure 1). The spines were collected from the same region, counting the number of spines per areole and measuring their size. These characteristics were recorded for both parents and progenies.

For the study of the hybrids and parental genetic divergence from the characteristics related to the cladodes, a genetic distance matrix was calculated, using the Euclidean distance, obtained by the following expression (CRUZ, 2006): (e01)

$$
d_{i i^{\prime}}=\sqrt{\sum_{j}\left(Y_{i j}-Y_{I^{\prime} J}\right)^{2}}
$$


where, $i$ and $i^{\prime}$;

$d_{\mathrm{ii}}$ : Euclidean distance between genotypes

$Y_{\mathrm{ii}}$ : Is the value obtained for the $\mathrm{i}$-th genotype in relation to the $\mathrm{j}=$ th variable.

From this matrix, the clustering analysis was performed using the UPGMA method (Unweighted Pair Group Method Using Arithmetic Averages). The adjustment between the genetic distances matrix and the generated dendrogram was calculated by the cophenetic correlation coefficient (r) (SOKAL and ROHLF, 1962). The relative contribution of each cladodes related characteristic to the estimation of genetic diversity was also studied by the Singh method (1981). All analyzes were performed using the Genes statistical program (CRUZ, 2006).

\section{RESULTS AND DISCUSSION}

The clustering analysis by the UPGMA method, using the six cladode characteristics for the 51 individuals evaluated (45 progenies and six parental) is presented in Figure 2. The cut in the dendrogram, plotted by the estimation of the average arithmetic complement (0.64), revealed the formation of six groups. The first group was formed of a subgroup containing 30 hybrids and four parental groups, being the group with the highest number of plants $(66.6 \%$ of the evaluated plants). The second group consisted of 11 plants, one parental [ $H$. Setaceus (L2P7)] and 10 hybrids (L4P11-10, L2P716, L2P17-7, L2P6-6, L4P11-21, L4P3-7, L2P7-1, L2P7-23, L4P11-19, and L2P7-21). The third and fourth groups were formed by single individuals, the third being represented by the hybrid L4P11-20 and the fourth by the L4P11-33. The fifth and sixth groups were formed by two individuals each, group $\mathrm{V}$ being formed by a hybrid (L4P3-13) and the mother plant (H. undatus), and the sixth group formed by plants L2P7-24 and L2P6-1. The genetic distances between the 51 plants ranged from 0.11 to 1.42 .

The cophenetic correlation coefficient of the obtained dendrogram $(r=0.77)$ indicates a good adjustment between the genetic distances matrix and the dendrogram (TAO et al., 2014). Although the plants come from seeds, some showed little dissimilarity between them. The most similar (least genetic distance) are L2P6-3 and L4P11-30 (0.11), hybrids from parents of different species - L2P6-3 comes from the crossing $H$. undatus $\mathrm{x} H$. setaceus (L2P6) and the Hybrid L4P11-30 is the result of the crossing $H$. undatus x $H$. polyrhizus (L4P11).

The most divergent (greatest distance) are L4P11-32 and L2P17-7 (1.42) - hybrids between $H$. undatus $\mathrm{x} H$. polyrhizus (L4P11) and H. undatus $\mathrm{x}$ H. polyrhizus (L2P17), but no genotype was $100 \%$ different from the other, even when comparing different species, which corroborates with the observation of Tel-Zur et al. (2004) on the pitaya narrow genetic base. The most similar hybrid to the mother plant (H. undatus) was the L4P3-13 individual (0.54). Evaluating wild and cultivated accessions of the species $H$. undatus and $H$. polyrhizus Tao et al. (2014) observed that the genetic distance ranged between 1.79 and 8.06 , and the highest variation was obtained among cultivated accesses.

In Brazil some researches realized by Junqueira et al. (2010a; 2010b) aim to study the genetic variability in pitayas access by means of molecular markers with RAPD technique. Comparing the accessions of $H$. undatus in the selection advanced phase, a small variation in the genetic distance was found that was of 0.006 to 0.148 . In the study comparing different native species, collected in different locations, the genetic distance between accessions was much higher, especially among plants of different genres, ranging between 0.088 and 0.848 . The lowest genetic distance was obtained between plants of the same species $(H$. setaceus) from different locations, but the genetic distance between plants of the same species ranged from 0.118 to 0.407 , reflecting great intraspecific variability.

The distances between the accessions and their distribution in the similarity groups can also be observed in the scatter plot (Figure 3 ). The diversity of the accessions L2P7-21 (6), L2P7-24 (9), L2P61 (10), L2P6-7 (16), L4P11-32 (30), L4P11-33 (31), L4P3 -13 (39), L4P3-21 (40) were observed in relation to the others. The progenies L4P3-13 and L2P6-1 present interesting characteristics for management, since they present small number of spines, and of smaller size than the average.

As for the contribution of each variable analyzed for the divergence between pitaya hybrids evaluated, it was observed that the cladode length had a greater influence $(83.26 \%$ ), whereas the size of the spine was the variable that exerted the least influence $(0,18 \%)$ (Table 2). Juárez Sandoval et al. (2007) state that the spines number and length characteristics, besides their arrangement in the areola, are reliable characteristics for the description of pitaya types of the genus Hylocereus. Grimaldo Juárez et al. (2007) found six morphological characters related to the cladode (size of the concave angle, height to the angle vertex, undulation height and spine number and length) as more important for genotype separation. Evaluating thirteen vegetative characters 
for differentiation of Hylocereus individuals from several localities in Mexico, García Aguilar (2007) found that seven characters were consistent for comparison among individuals, even those exposed to solar radiation or in a shaded environment, such as: cornification, number of edges, waxy, diameter, number and size of the spines. Tao et al. (2014) observed that the thickness of the rib was the most significant, among the cladode characters, for genotype differentiation. Grimaldo Juárez et al. (2007) reported that cladode traits were more efficient than floral traits for group separation, although traits associated with plant reproductive organs are generally more stable than vegetative traits (FLÁVIO, 2010).
Although many authors find positive results, it is known that morphological and agronomic characters used to measure genetic diversity in certain populations of individuals often do not allow the identification of discrete taxonomic groups, since most of the plant characters are influenced by environmental factors, exhibiting continuous variation and high degree of phenotypic plasticity (FLÁVIO, 2010). This plasticity can be considered a form of plant adaptation to environmental conditions in which they are. Also, according to Tel-Zur et al. (2004), the separation of species and varieties in the genus Hylocereus is difficult due to the high intra and interspecific hybridization that occurs in this species.

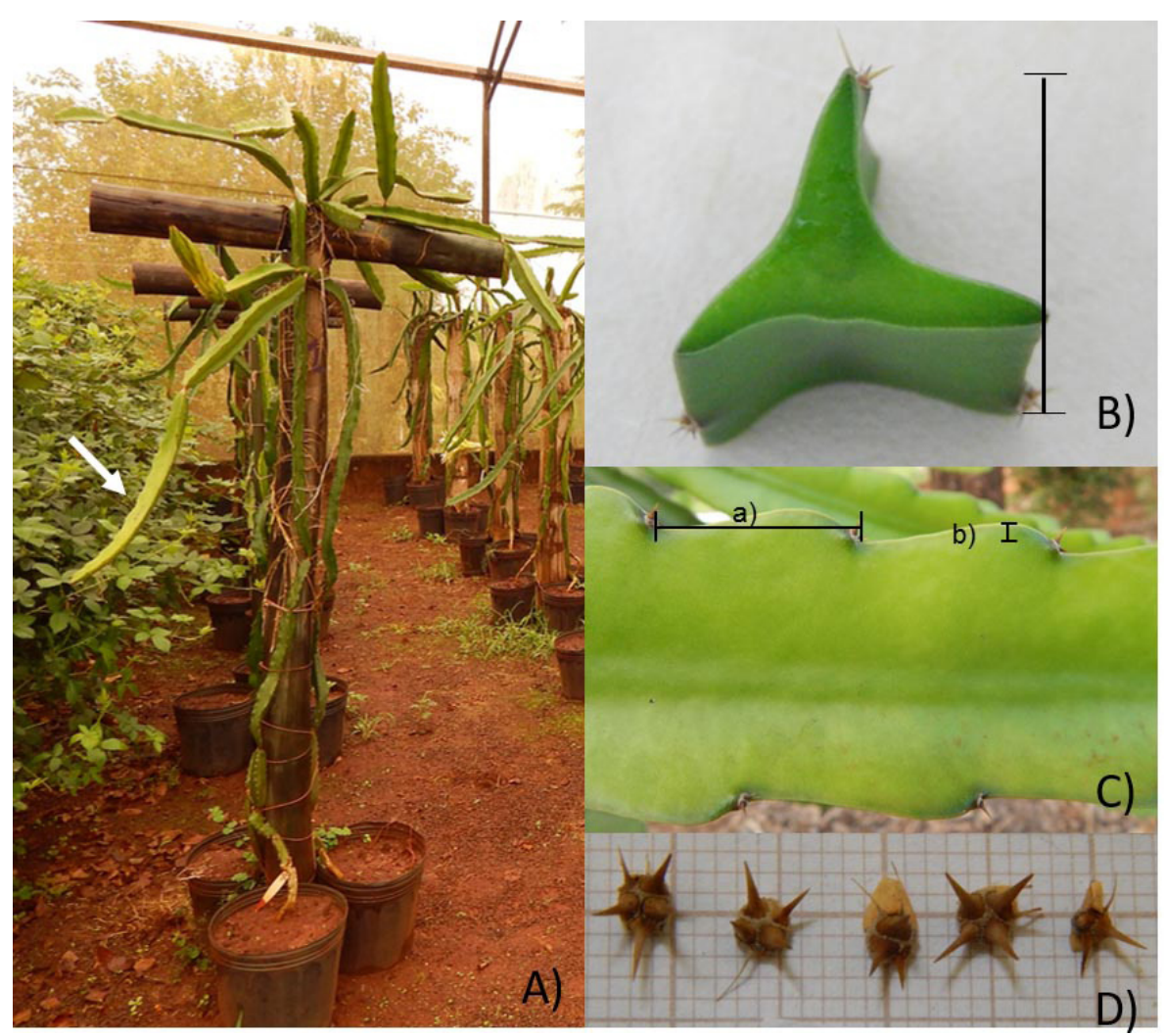

FIGURE 1-A) Secondary cladodes for measuring length and diameter (indicated by the arrow); B) Diameter measurement; C) Measure of the distance between areolas (a) and arch height (b); D) Spines for measuring number and length. FCAV, UNESP, Jaboticabal, 2014. 
TABLE 1 - Mean values of morphological descriptors evaluated in pitaya hybrids and parents. FCAV/ UNESP, Jaboticabal, 2014.

\begin{tabular}{|c|c|c|c|c|c|c|}
\hline ACESS & LENG & DIAM & DIST & ARCH & SNUM & SLEN \\
\hline$\overline{L 2 P 7-1}$ & 56.50 & 29.17 & 41.23 & 1.97 & 3.8 & 3.88 \\
\hline L2P7-3 & 26.67 & 28.74 & 33.04 & 3.85 & 3.6 & 1.22 \\
\hline L2P7-4 & 30.50 & 25.93 & 36.55 & 4.23 & 4.4 & 1.98 \\
\hline L2P7-16 & 50.25 & 24.29 & 36.38 & 2.82 & 3.8 & 3.52 \\
\hline L2P7-18 & 26.00 & 22.23 & 33.46 & 4.38 & 4.4 & 1.94 \\
\hline L2P7-21 & 34.75 & 34.61 & 40.07 & 4.15 & 4.8 & 2.70 \\
\hline L2P7-22 & 62.00 & 29.90 & 34.43 & 2.16 & 4.2 & 1.68 \\
\hline L2P7-23 & 36.50 & 32.07 & 41.35 & 3.00 & 3.8 & 1.59 \\
\hline L2P7-24 & 89.50 & 30.70 & 37.06 & 4.74 & 4.0 & 1.67 \\
\hline L2P6-1 & 96.50 & 25.63 & 37.43 & 3.03 & 2.0 & 1.63 \\
\hline L2P6-2 & 27.67 & 23.92 & 27.90 & 2.36 & 4.2 & 3.91 \\
\hline L2P6-3 & 25.17 & 29.85 & 24.94 & 2.96 & 3.6 & 2.83 \\
\hline L2P6-4 & 39.00 & 21.27 & 35.06 & 2.85 & 4.8 & 2.19 \\
\hline L2P6-5 & 28.00 & 23.21 & 27.04 & 3.31 & 4.4 & 2.50 \\
\hline L2P6-6 & 41.33 & 29.09 & 36.35 & 3.59 & 3.6 & 3.39 \\
\hline L2P6-7 & 40.00 & 22.22 & 30.22 & 2.59 & 6.0 & 2.20 \\
\hline L4P11-1 & 35.00 & 26.17 & 30.58 & 2.8 & 5.0 & 1.78 \\
\hline L4P11-7 & 18.50 & 21.23 & 26.87 & 3.19 & 4.4 & 3.48 \\
\hline L4P11-10 & 33.00 & 18.76 & 40.01 & 3.99 & 3.4 & 3.45 \\
\hline L4P11-15 & 52.00 & 26.01 & 31.37 & 5.12 & 2.8 & 2.39 \\
\hline L4P11-16 & 49.75 & 24.81 & 28.92 & 4.08 & 2.6 & 1.86 \\
\hline L4P11-17 & 37.67 & 26.24 & 25.57 & 3.78 & 3.4 & 2.16 \\
\hline L4P11-18 & 54.33 & 26.49 & 26.53 & 3.12 & 3.8 & 1.94 \\
\hline L4P11-19 & 27.50 & 26.34 & 45.12 & 3.09 & 3.8 & 1.98 \\
\hline L4P11-20 & 29.67 & 24.50 & 38.46 & 3.04 & 5.2 & 5.28 \\
\hline L4P11-21 & 28.50 & 26.63 & 34.5 & 3.30 & 4.0 & 3.89 \\
\hline L4P11-22 & 24.00 & 25.72 & 33.47 & 2.82 & 3.2 & 2.73 \\
\hline L4P11-25 & 28.50 & 25.38 & 30.28 & 2.53 & 3.8 & 2.42 \\
\hline L4P11-30 & 29.33 & 30.19 & 24.64 & 3.19 & 3.2 & 2.76 \\
\hline L4P11-32 & 18.50 & 19.02 & 20.39 & 3.21 & 4.6 & 2.48 \\
\hline L4P11-33 & 22.00 & 23.93 & 38.52 & 3.53 & 6.4 & 2.76 \\
\hline L4P3-1 & 36.67 & 24.51 & 33.02 & 3.35 & 3.6 & 2.33 \\
\hline L4P3-2 & 19.00 & 31.68 & 28.13 & 2.87 & 4.2 & 2.14 \\
\hline L4P3-6 & 21.00 & 25.02 & 22.78 & 3.22 & 4.6 & 3.59 \\
\hline L4P3-7 & 31.67 & 28.55 & 40.55 & 2.71 & 4.4 & 3.47 \\
\hline L4P3-8 & 29.00 & 23.88 & 32.10 & 3.10 & 3.6 & 2.62 \\
\hline L4P3-10 & 14.00 & 22.43 & 34.74 & 1.71 & 4.4 & 2.69 \\
\hline L4P3-12 & 53.33 & 34.35 & 30.58 & 3.55 & 3.4 & 2.95 \\
\hline L4P3-13 & 51.00 & 39.63 & 37.65 & 5.14 & 2.8 & 1.94 \\
\hline L4P3-21 & 23.17 & 23.14 & 29.63 & 3.42 & 5.4 & 3.81 \\
\hline L4P3-22 & 23.00 & 28.52 & 33.87 & 3.90 & 4.4 & 2.21 \\
\hline L4P3-30 & 49.17 & 26.94 & 32.68 & 3.14 & 3.6 & 2.32 \\
\hline L4P3-31 & 59.33 & 28.05 & 28.78 & 2.97 & 4.8 & 2.39 \\
\hline L2P17-1 & 37.75 & 25.72 & 28.74 & 3.46 & 2.8 & 2.54 \\
\hline L2P17-7 & 52.67 & 22.36 & 39.61 & 3.32 & 3.0 & 3.37 \\
\hline H. undatus & 35.00 & 35.63 & 42.58 & 7.22 & 3.4 & 2.61 \\
\hline L2P6 (H. setaceus) & 27.67 & 19.00 & 35.53 & 2.50 & 4.0 & 1.72 \\
\hline L2P7 (H. setaceus) & 30.00 & 21.81 & 38.13 & 3.23 & 3.4 & 2.89 \\
\hline L2P17 (H. polyrhizus) & 22.67 & 25.13 & 24.35 & 2.94 & 4.4 & 2.62 \\
\hline L4P3 (H. polyrhizus) & 19.33 & 28.96 & 19.45 & 3.74 & 4.2 & 2.85 \\
\hline L4P11 (H. polyrhizus) & 31.00 & 21.85 & 34.04 & 2.78 & 4.0 & 2.55 \\
\hline
\end{tabular}

LENG, DIAM - length and diameter of cladodes (cm); DIST - distance between areoles (mm); ARCH - arch height $(\mathrm{mm})$; SNUM - spines number per areole; SLEN - spine length (mm). 


\section{Grouping method: Average link among groups}

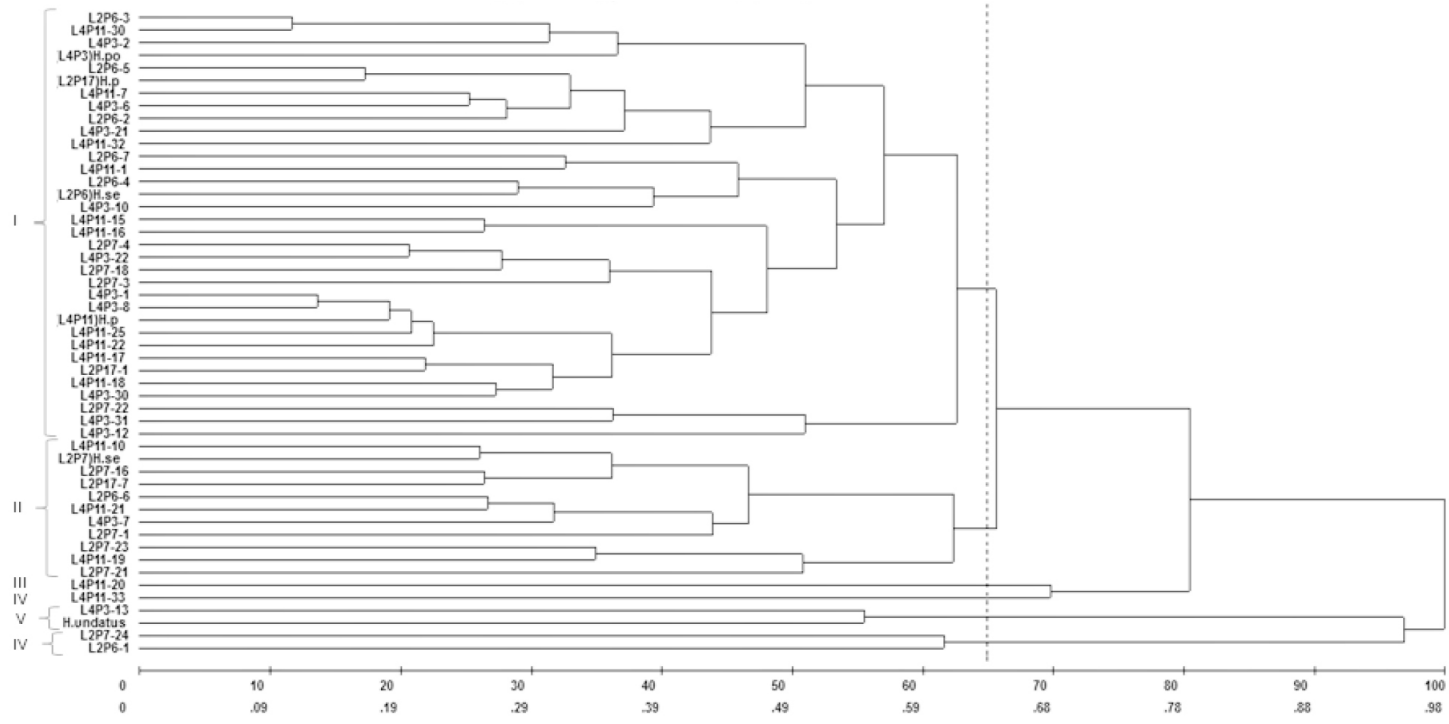

FIGURE 2-Genetic distance dendrogram of 51 pitaya individuals (based on 6 characters related to the cladode), obtained by the UPGMA method and using the Euclidian distance as a measure of genetic distance. FCAV, UNESP, Jaboticabal, 2014.

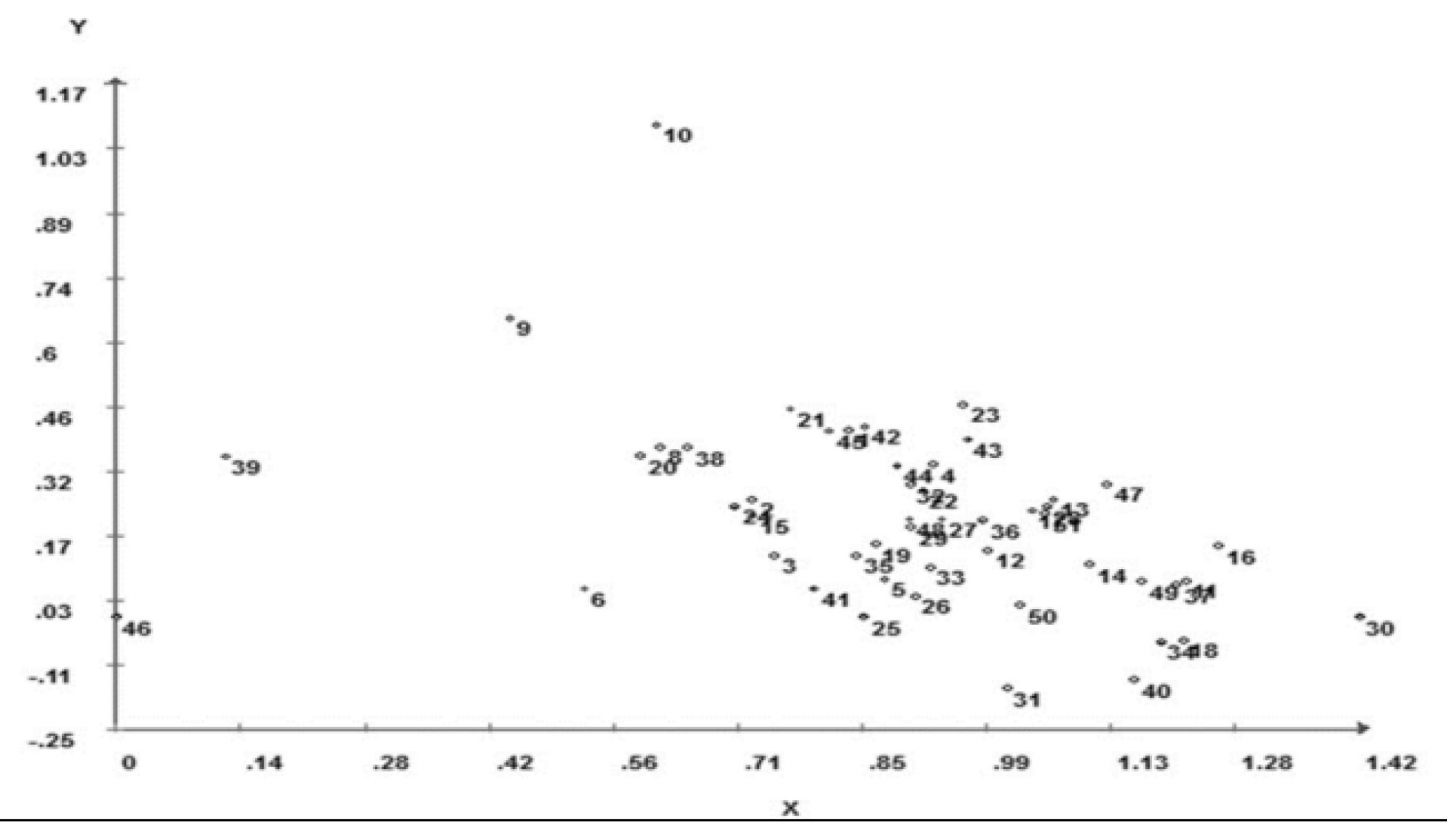

FIGURE 3- Graphical dispersion of 51 pitaya individuals (Table 1) based on the Euclidean distance matrix, using 6 morphological characteristics of the cladode. FCAV, UNESP, Jaboticabal, 2014. 
TABLE 2- Contribution, in percentage of each variable evaluated for the divergence among the pitaya hybrids evaluated, by Singh method (1981). FCAV, UNESP, Jaboticabal, 2014.

\begin{tabular}{lc}
\hline \multicolumn{1}{c}{ VARIABLE } & VALUE(\%) \\
\hline Cladode length & 83.26 \\
Cladode diameter & 56.25 \\
Distance between areoles & 10.48 \\
Arch height & 0.24 \\
Spine number per areole & 0.20 \\
Spine size & 0.18 \\
\hline
\end{tabular}

\section{CONCLUSIONS}

The evaluated hybrids presented high genetic distance, showing great variability. The hybrids L4P3-13, L4P3-21, L4P11-32, L4P11-33, L2P721, L2P7-24, L2P6-1 and L2P6-7 showed to have potential to be evaluated in a breeding program.

\section{ACKNOWLEDGEMENTS}

We would like to thank FAPESP (process 2011 / 17171-7) for granting a doctorate scholarship to the first author.

\section{REFERENCES}

ANDRADE, R. A.; MARTINS, A. B. G. Aspectos morfológicos de folhas na diferenciação de variedades de carambola. Revista Brasileira de Fruticultura, Jaboticabal, v.29, n.2, p.386-388, 2007.

CRUZ, C. D. Programa GENES. Análise multivariada e simulação. Viçosa: Editora UFV, 2006. 175 p.

FLÁVIO, J. J. P. Divergência genética entre árvores matrizes de Guazuma ulmifolia Lam. 2010. 87 f. Dissertação (Mestrado em Agronomia - Genética e Melhoramento de Plantas) - Faculdade de Ciências Agrárias e Veterinárias, Universidade Estadual Paulista, Jaboticabal, 2010.
GARCÍAAGUILAR, M. A. Anatomía y morfología de las especies silvestres del género Hylocereus (Berger) Britton \& Rose (Cacaceae) en México. 2007. 58 f. Tesis (Maestria en Ciencias). Institución de Enseñanza e Investigación en Ciencias Agrícolas, Colegio de Postgraduados, Campus Montecillo, Texcoco, México. 2007.

GRIMALDO JUÁREZ, O.; TERRAZAS, T.; GARCÍA VELÁSQUEZ, A.; PONCE-MEDINA, J. F. Morphometric analysis of 21 pitahaya (Hylocereus undatus) genotypes. Journal of the Professional Association for Cactus Development, Dakota Cir, v.9., p.99-117, 2007.

JUÁREZ SANDOVAL, I.; RAMÍREZ MIRELES, F. J.; CRUZ HERNÁNDEZ, T. caracterización de dos clones de pitahaya roja (Hylocereus purpusii) de Jalisco, Mexico. Revista Chapingo Serie Zonas Aridas, Chapingo, v.8, p.115-122, 2009.

JUNQUEIRA, K. P.; FALEIRO, F. G.; BELLON, G.; JUNQUEIRA, N. T. V.; FONSECA, K.G.; LIMA, C. A.; SANTOS, E. C. Variabilidade genética de acessos de pitaya com diferentes níveis de produção por meio de marcadores RAPD. Revista Brasileira de Fruticultura, Jaboticabal, v.32, n.3, p.840-846, 2010a.

JUNQUEIRA, K. P.; FALEIRO, F. G.; JUNQUEIRA, N. T. V.; BELLON, G.; LIMA, C. A.; SOUZA, L. S. Diversidade genética de pitayas nativas do cerrado com base em marcadores RAPD. Revista Brasileira de Fruticultura, Jaboticabal, v.32, n.3, p.819-824, 2010 b. 
ORTIZ HERNÁNDEZ, Y. D.; CARRILLO SALAZAR, J. A. Pitahaya (Hylocereus spp): a short review. Comunicata Scientiae, Bom Jesus, v.3, n.4, p.220-237, 2012

SOKAL, R. R.; ROHLF, F. J. The comparison of dendrograms by objective methods. Taxon, Vienna, v.11, p.33-40, 1962.

TAO, J.; QIAO, G.; WEN, X. P.; GAO, G. L.; LIU, T.; PENG, Z. J.; CAI, Y. Q.; CHEN, N.; YAN, F. X.; ZHANG, B. X. Characterization of genetic relationship of dragon fruit accessions (Hylocereus spp.) by morphological traits and ISSR markers. Scientia Horticulturae, Amsterdam, v.170, p.82-88, 2014.
TEL-ZUR, N.; ABBO, S.; BAR-ZVI, D.; MIZRAHI, Y. Genetic relationships among Hylocereus and Selenicereus Vine Cacti (Cactaceae): evidence from hybridization and cytological studies. Annals of Botany, Oxford, v. 94, p.527-534, 2004.

UPOV - International Union for The Protection of New Varieties of Plants. Guidelines for the conduct of tests for distinctness, uniformity and stability - dragon fruit. Geneva, 2011. 33p. 